\title{
editorial
}

\section{Archaeological Dialogues and regional archaeological projects}

As was stated in the editorial published in the first issue of Archaeological Dialogues in 1994, promotion of 'debate among the various continental traditions and to stimulate their regional diversity' is one of the explicit aims of this journal. The concomitant wish to provide a 'forum for interdisciplinary debate both on a wide range of archaeological and related themes on the basis of a particular archaeological or ethnographic situation, and on specific archaeological problems of a given region and period' has always been the cornerstone of editorial policy. Whereas Archaeological Dialogues strives to realize these goals at an international scale, similar concerns had already prompted the organization of a Dutch national conference in 1990. Within the Netherlands, this first meeting has since then developed into the annual Dutchlanguage 'Symposium on Archaeology and Theory' which is attended by a large part of the Dutch archaeological community.

The fifth anniversary of the annual symposium has been seized as an opportunity to broaden debate and to invite a number of internationally-reputed archaeologists to exchange views with their Dutch colleagues. As regional archaeological projects have always been an important feature of Dutch archaeology, a three-day English-language international conference was organized under the heading of The history, theory and methodology of regional archaeological projects. It took place in Leiden from 17th until 19th January 1996. Much attention was given to comparisons of specific regional projects both in north-western Europe and the Mediterranean as well as to outlining and analyzing general trends; other sessions dealt with more specific issues such as the application of GIS and matters of cultural identity and heritage.

Given the close connections between the Symposium on Archaeology and Theory and Archaeological Dialogues, it seems appropriate that a selection of the papers presented at the conference in Leiden is published in this journal. The present issue of Archaeological Dialogues thus includes a special section on The history, theory and methodology of regional archaeological projects, while the next one (4.1, to appear in 1997) will include two more sections on the role of GIS and questions of cultural identity in relation to regional projects. The latter theme is already addressed at length in this issue by the anthropologist Peter Odermatt, who in the discussion article Built heritage and the politics of (re)presentation. Local reactions to the appropriation of the monumental past in Sardinia provides an ethnographic account on how a local community has been affected by the combined efforts of the heritage industry to create an authoritative, imaginative past aróund socially meaningful historic sites. Focusing on one of the most famous archaeological attractions in Sardinia, the nuraghe Losa near Abbasanta, he particularly draws attention to the interrelations between identity formation, heritage conservation and tourism.

Both the conference in Leiden and the additional pages for the publication of the papers have been made possible thanks to the generous support of the Dutch National Research School for Advanced Studies in Archaeology (ARCHON). (PvD) 